\title{
INFORMATION TECHNOLOGY, GREEN INITIATIVES AND ORGANIZATIONAL PERFORMANCE: CONTINGENCY MODELS
}

\author{
Yunitha Ardiana Nur ${ }^{1}$, Rr. Endang Wahyuni ${ }^{2}$, Deslida Saidah ${ }^{3}$, Reni Dian \\ Octaviani $^{4}$
}

1. STMT Trisakti, 2. STMT Trisakti, 3. STMT Trisakti, 4. STMT Trisakti

$\square$ corresponding author: yunitha.nur@gmail.com

\begin{abstract}
Green initiatives are one of the main topics in environmental sustainability research area. Environmental sustainability itself is known as a preferable achieving from sustainable transportation. Although service industries have a smaller environmental impact than manufacturing industries, transportation and logistics service activities should play a significant role in reducing their adverse impact. The aim of this paper is to develop a theoretical framework of the implications of the alignment between information and communication technology (ICT) and green transportation and logistics service provider initiatives for organizational performance using a contingency theory perspective. The framework provides a structure for empirical analysis of the relationship between ICT supporting green initiative and performance. The results demonstrate that the theoretical framework would support empirical analysis of the importance of ICTs in supporting the adoption of green initiatives at different perspectives, namely matching, mediation and moderation.

Keywords: green initiatives, alignment, contingency theory, transportation and logistics service
\end{abstract}

\section{Introduction}

Green initiatives are one of the main topics in environmental sustainability research area. Environmental sustainability itself is known as a preferable achieving from sustainable transportation. In spite of the fact service industries role in reducing environmental impact is less significant than manufacturing industries, but transportation and logistics service provider still need to adopt green initiatives as their contribution of carbon dioxide emissions, pollution, noise, and others on environment (Greene, 2015; Ismiyati, Marlita, \& Saidah, 2014; Kadarisman, 2015; Sitorus, Hidayat, \& Prasetya, 2014). Moreover, transportation and logistics service industries together with manufacturing and customers working for environmental sustainability (Rahayu \& Adhi, 2015). 
Based on Centobelli, Cerchione, \& Esposito (2017a) there are several literature gaps regarding the understandings of green initiatives (e.g. classification of green initiatives, the impact of green initiatives on organizational performance, ICTs supporting green initiatives and the need a more comprehensive empirical investigation in the logistics service industry). Concerning these, it needs to develop a theoretical framework for understanding the degree of alignment between ICTs used by transportation and logistics service provider and their green initiatives to support their organizational performance (Samekto \& Soejanto, 2014). Hence, this paper describes a theoretical model that illustrates proposed links between ICT and green initiative alignment and organizational performance, as a basis for comprehensive empirical investigation furthermore.

\section{Method}

Contingency theory is applied to this paper. At the first time, contingency theory was introduced by Burns and Stalker (1961) through the publication of "the management of innovation". The reasons of utilizing contingency theory are: first, it can be applied to measure performance as a dependent variable; second, it can assist researchers to assess the degree of alignment between two variables as its key concept is fit; third, it has been applied to an extensive research in the fields of business and information technology (e.g. Chan, Huff, Barclay, \& Copeland, 1997), logistics or supply chain (e.g. Flynn, Huo, \& Zhao, 2010) and strategic management (e.g. Drazin \& Van de Ven, 1985); and fourth, it has a capacity to analyze the relationship of variables through fit, mediation and moderation which used broadly in frameworks for empirical studies as Dubin (1976) stated every theory is a contingency theory.

This paper employed a descriptive design with a qualitative approach. We applied problems identified on Centobelli et al. (2017a) and develop a theoretical framework of the effect of alignment between ICTs used by transportation and logistics service provider and their initiatives on firm 
performance based on replication of Chan et al. (1997) and Bergeron, Raymond, and Rivard (2001). The theories or models described under contingency perspectives, based on the notion of "fit" or "alignment" between the organization's management of ICT and green initiatives. The study examines three perspectives to pertain the relationships between ICT, green initiatives and organizational performance, namely matching, mediation and moderation as bivariate approaches to alignment. Results obtained from applying and comparing the three perspectives illustrate their significant differences and confirm the need for following up with empirical study to understand research in the area.

\section{Results and Discussion}

\section{Results}

This paper utilized three variables namely green initiatives and ICT strategy as the independent variables, and firm performance as the dependent variable. The first variable was a version of Colicchia, Marchet, Melacini, and Perotti's variable (2013). The seventh dimensions of green initiatives derived from Colicchia et al. (2013) are internal management, collaboration with customers, external collaborations, packaging management, distribution strategies and transportation execution, warehousing and green building, and reverse logistics.

The second variable was created by the researchers to determine the nature of the ICTs that had been used by transportation and logistics service providers are appropriate to support their green initiatives. The variable was designed parallel for each individual item of green initiative as replicate Chan et al. (1997). The seventh dimensions of ICT strategy are ICT support for internal management, ICT support for collaboration with customers, ICT support for external collaborations, ICT support for packaging management, ICT support 
for distribution strategies and transportation execution, ICT support for warehousing and green building, and ICT support for reverse logistics.

The third variable is firm performance. Chan et al. (1997) noted that firm performance can be assessed in multiple measures, either financial and non financial, using company's data or perception from the key informants. This paper utilizes firm performance from Chan et al.'s version as Centobelli et al. (2017a) emphasized the need to assess the impact of green initiatives on market performance and organizational performance. The fourth dimensions of firm performance are market growth, financial performance, service innovation, and company reputation. Table 1 outlines the dimensions of these three variables.

Table 1. Dimension of Variables

1. Green initiatives - Multifaceted concept which incorporates three perspectives: the managerial, organizational, and technological perspective (Centobelli, Cerchione, \& Esposito, 2017b)

\begin{tabular}{|c|c|}
\hline Internal management & $\begin{array}{l}\text { Internal management initiatives to be } \\
\text { involved in environmental sustainability } \\
\text { (Colicchia et al. 2013) - the managerial } \\
\text { perspective }\end{array}$ \\
\hline Collaboration with customers & $\begin{array}{l}\text { Company takes initiatives to educate the } \\
\text { customers get involved in transportation and } \\
\text { logistics activities (Colicchia et al. 2013) - } \\
\text { the organizational perspective }\end{array}$ \\
\hline External collaborations & $\begin{array}{l}\text { Company takes initiatives to promote } \\
\text { environmental collaboration with shippers } \\
\text { and suppliers (Colicchia et al. 2013) - the } \\
\text { organizational perspective }\end{array}$ \\
\hline Packaging management & $\begin{array}{l}\text { Company takes initiatives to manage } \\
\text { packaging activities in a more } \\
\text { environmentally kind way (Colicchia et al. } \\
2013 \text { ) - the organizational perspective }\end{array}$ \\
\hline
\end{tabular}


Table 1, Cont. Dimension of Variables

Distribution strategies and transportation Company gives attention in distribution and execution sustainable transportation execution through technological innovation and management strategies (Colicchia et al. 2013) - the technological perspective

Warehousing and green building Company takes initiatives to utilize ecofriendly warehouse design and energy efficiency (Colicchia et al. 2013) - the organizational perspective

Reverse logistics Company intend to control waste and disposal properly (Colicchia et al. 2013) the organizational perspective

2. ICTs strategy - The extent to which ICTs used by transportation and logistics service provider facilitate their green initiatives on internal management, collaboration with customers, external collaborations, packaging management, distribution strategies and transportation execution, warehousing and green building, and reverse logistics (Chan et al. (1997).

ICT Support for Internal management

CT Support for Collaboration with customers

ICT Support for External collaborations

\begin{abstract}
ICTs deployments used by transportation and logistics service provider when assisting internal management involve in environmental sustainability

ICTs deployments used by transportation and logistics service provider when facilitating company's initiatives to educate the customers get involved in transportation and logistics activities

ICTs deployments used by transportation and logistics service provider when improving company's initiatives to promote environmental collaboration with shippers and suppliers
\end{abstract}


Table 1, Cont. Dimension of Variables

ICT Support for Packaging management

ICTs deployments used by transportation and logistics service provider to expedite company's initiatives to manage packaging activities in a more environmentally kind way

ICT Support for Distribution strategies and transportation execution

ICTs deployments used by transportation and logistics service provider to strengthen company's attention in distribution and sustainable transportation execution through technological innovation and management strategies

ICT Support for Warehousing and green building

ICTs deployments used by transportation and logistics service provider to make utilization of eco-friendly warehouse design and energy efficiency

ICT Support for Reverse logistics

ICTs deployments used by transportation and logistics service provider to improve controlling waste and disposal properly

\begin{tabular}{ll}
\hline 3. Firm Performance - Perceived Current Firm Achievement (Chan et al. 1997) \\
\hline Market Growth & e.g., market share gains (Chan et al. 1997) \\
Financial Performance & e.g., return on investment (Chan et al. 1997) \\
Service Innovation & e.g., developments in services (Chan et al. \\
& 1997) \\
Company Reputation & e.g., reputation among transportation and \\
& logistics service provider (Chan et al. 1997) \\
\hline
\end{tabular}

Based on Venkatraman (1989) we utilize three perspective of fit or alignment in order to propose frameworks to explain the relationship of ICTs supporting green initiatives to increase firm performance. These perspectives are also adapted in Bergeron, et al. (2001). Alignment can be defined as matching, mediation and moderation. The following figures describe each perspective of alignment as matching (Fig. 1), mediation (Fig. 2), and moderation (Fig. 3). 


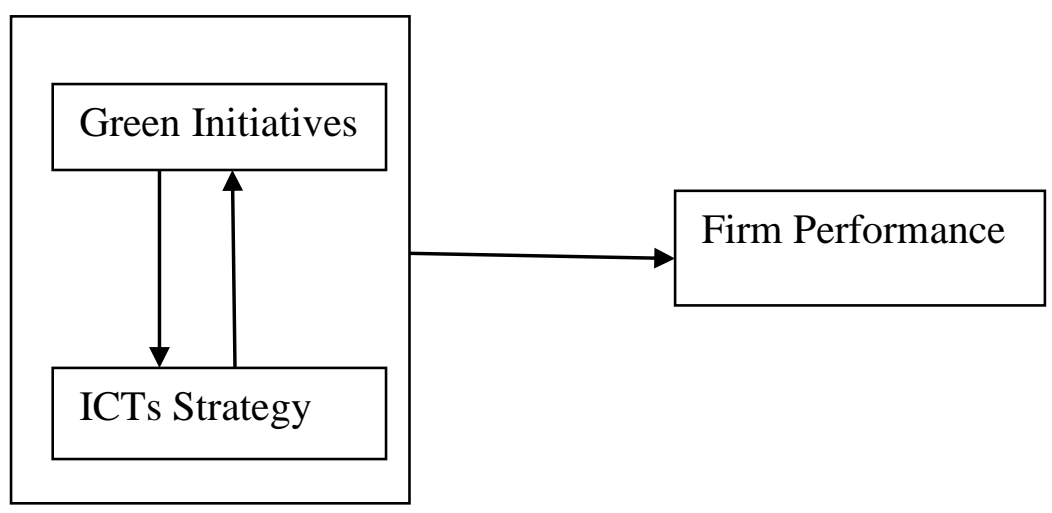

Figure 1. Alignment as matching

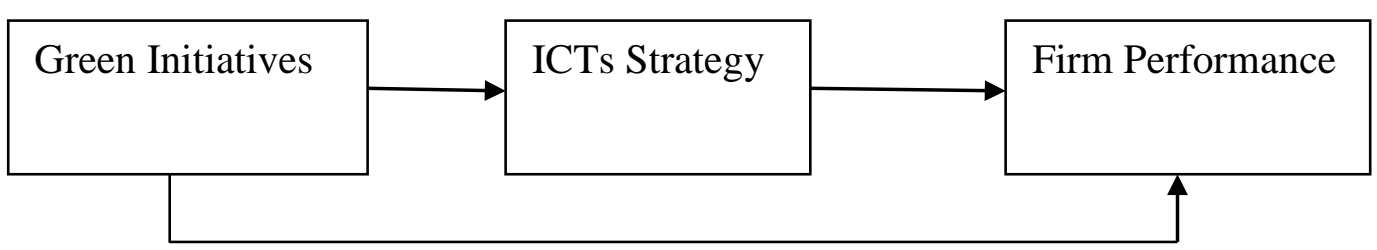

Figure 2. Alignment as mediation

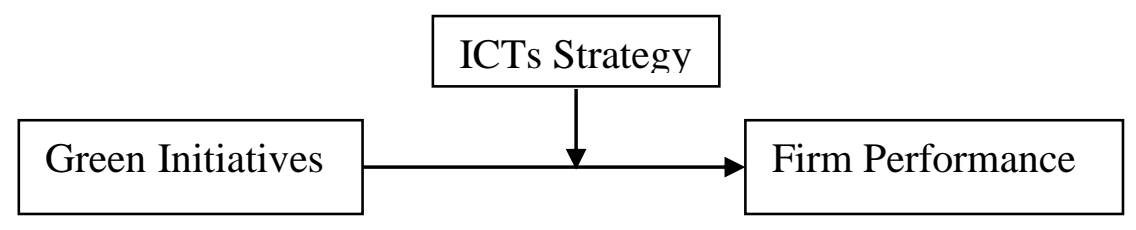

Figure 3. Alignment as moderation

\section{Discussion}

Alignment as matching is defined congruence between ICTs and green initiatives by replicating Bergeron et al. (2010). It can effect organizational performance through hypothesis that the greater the alignment between ICTs and green initiatives, the greater the extent of organizational performance. The hypothesis test could use hierarchical regression (Sudarno, 2005). The alignment effect on organizational performance could be measured by statistical value of $t$ and $\beta$.

Alignment as mediation is defined ICTs acts as intervening between green initiatives and organizational performance. The hypothesis test of this could use 
hierarchical regression (Sudarno, 2005). There is no direct relationship between green initiatives and organizational performance without ICTs.

Alignment as moderation is defined the impact of green initiatives on organizational performance is dependent on ICTs which acts as the moderator. The hypothesis test of this could use hierarchical regression also (Sudarno, 2005). ICTs will influence the relationship of green initiatives and organizational to be more strong.

\section{Conclusion}

Results of this paper are theoretical frameworks which contributed to our understanding of ICTs supporting green transportation and logistics provider initiatives in the following ways: First, this study integrated and expanded on, earlier research in the area (e.g., Bergeron et al., 2001; Centobelli et al., 2017; Chan et al., 1997; Colicchia et al., 2013). Alternative perspectives were developed, as matching, mediation, and moderation approaches to developing model the relationship between the ICTs and green initiative alignment and organizational performance. Entirely new dimensions of ICTs strategy were also introduced. Variables were described only qualitatively in much of the current green initiatives literature.

Second, the study presented and explored bivariate models of ICT and green initiative alignment and performance. Furthermore, the frameworks can be applied to assess statistically how firm performance increases through the alignment of ICTs strategy and green initiatives. Based on Venkatraman (1989) the degree of alignment between ICTs strategy and green initiatives as matching can be assessed by using correlation analysis if the correlation coefficient is larger than 0.10 . The role of alignment between ICTs strategy and green initiatives as mediation can be assessed by using hierarchical regression analysis $\mathrm{Y}=\mathrm{c}+\beta 1 \mathrm{X} 1+\beta 2 \mathrm{X} 2+\mathrm{e}$; where $\mathrm{X} 1$ is green initiatives, $\mathrm{X} 2$ is ICTs strategy, and $\mathrm{Y}$ is firm performance. The role of alignment between ICTs strategy and green initiatives as moderation can be assessed by using 
hierarchical regression analysis $\mathrm{Y}=\mathrm{d}+\beta 3 \mathrm{X} 1+\beta 4 \mathrm{X} 2+\beta 5 \mathrm{X} 1 * \mathrm{X} 2+\mathrm{e}$; where $\mathrm{X} 1$ is green initiatives, $\mathrm{X} 2$ is ICTs strategy, $\mathrm{X} 1 * \mathrm{X} 2$ is reciprocal impact between green initiatives and ICTs strategy, and Y is firm performance.

Third, this paper described theoretical frameworks which need to examine furthermore to describe the indicators for each variable. Afterwards, the indicators will lead to create the instruments to measure each variable.

\section{References}

Bergeron, F., Raymond, L., \& Rivard, S. (2001). Fit in strategic information technology management research: An empirical comparison of perspectives. Omega, 29, 125-142. https://doi.org/10.1016/S03050483(00)00034-7

Burns T., \& Stalker G. M. (1961). The management of innovation. London, UK: Tavistock Publications.

Centobelli, P., Cerchione, R., \& Esposito, E. (2017a). Environmental sustainability in the service industry of transportation and logistics service providers: Systematic literature review and research direction. Transportation Research Part D, 53, 454-470. https://doi.org/10.1016/j.trd.2017.04.032

Centobelli, P., Cerchione, R., \& Esposito, E. (2017b). Developing the $\mathrm{WH}^{2}$ framework for environmental sustainability in logistics service providers: A taxonomy of green initiatives. Journal of Cleaner Production, 165, 1063-1077. https://doi.org/10.1016/j.jclepro.2017.07.150

Chan, Y. E., Huff, S. L., Barclay, D. W., \& Copeland, D. G. (1997). Business strategic orientation, information systems strategic orientation, and strategic alignment. Information Systems Research, 8(2), 125-150. https://doi.org/10.1287/isre.8.2.125

Colicchia, C., Marchet, G., Melacini, M., \& Perotti, S. (2013). Building environmental sustainability: Empirical evidence from logistics service providers. Journal of Cleaner Production, 59, 197-209. https://doi.org/10.1016/j.jclepro.2013.06.057

Drazin R., \& Van de Ven A. H. (1985). Alternative forms of fit in contingency theory. Administrative Science Quarterly, 30(4), 514-539. DOI: $10.2307 / 2392695$

Dubin, R. (1976). Theory building in applied areas. In M. Dunnette (Ed.), Handbook of industrial and organizational psychology (pp. 17-39). Chicago: Rand McNally.

Flynn, B. B., Huo, B., \& Zhao, X. (2010). The impact of supply chain integration on performance: A contingency and configuration approach. 
Journal of Operations Management, 28, 58-71. https://doi.org/10.1016/j.jom.2009.06.001

Green, D. L. (2015). Sustainable transportation. International Encyclopedia of the Social \& Behavioral Sciences, 23, 845-849.

Ismiyati, Marlita, D., \& Saidah, D. (2014). Pencemaran udara akibat emisi gas buang kendaraan bermotor. Jurnal Manajemen Transportasi \& Logistik, 01(03), 241-247. http://dx.doi.org/10.25292/j.mtl.v1i3.23

Kadarisman, M. (2015). Transportation system and human needs in a family. Jurnal Manajemen Transportasi \& Logistik, 02(03), 313-331. http://dx.doi.org/10.25292/j.mtl.v2i3.113

Rahayu, W.P., \& Adhi, W. (2015). Penerapan 'good logistics practices' sebagai penunjang ekspor buah tropis. Jurnal Manajemen Transportasi \& Logistik, 02(01), 93-105. http://dx.doi.org/10.25292/j.mtl.v2i1.133

Samekto, A.A., \& Soejanto (2014). Peningkatan kinerja perusahaan ekspedisi muatan kapal laut melalui diversifikasi usaha. Jurnal Manajemen Transportasi \& Logistik, 01(01), 1-13. http://dx.doi.org/10.25292/j.mtl.v1i1.3

Sitorus, B., Hidayat, R.D.R., \& Prasetya, O. (2014). Pengelolaan penggunaan bahan bakar minyak yang efektif pada transportasi darat. Jurnal Manajemen Transportasi \& Logistik, 01(02), 117-126. http://dx.doi.org/10.25292/j.mtl.v1i2.12

Sudarno. (2005). Sistem perakaunan pengurusan dan keberkesanan organisasi: Peranan budaya organisasi (Unpublished Ph.D Dissertation). Penang, MY: Universiti Sains Malaysia.

Venkatraman N. (1989). The concept of fit in strategy research: Toward verbal and statistical correspondence. Academy of Management Review, 14(3), 423-444. doi: 10.5465/AMR.1989.4279078 